\title{
The New Politics of Class after the 2017 General Election ${ }^{1}$
}

James Tilley (University of Oxford and Jesus College, Oxford)

Geoffrey Evans (University of Oxford and Nuffield College, Oxford)

The first thing to do is, of course, thank the four authors for all of their thoughts on the New Politics of Class (from now on NPC). In this response, we want to both address some of the issues that they raise, but also reflect a little on our findings and conclusion in the light of the 2017 general election. Before doing either of these, it is perhaps worth setting out the main argument of the book which focuses on three main claims about British politics since 1945. First, ideological divisions among people due to occupational class and education have been fairly constant over the last seventy years. Second, parties have changed, and this change was a one off shock to the system in the 1990s with the emergence of New Labour. And third, this combination of voter continuity and party change resulted in a large decline in class voting for the main parties in the 1990s and a delayed, but equally large, increase in class non-voting in the 2000s.

The aspect of the first proposition that both Eric Kaufmann and Mike Savage pick up on is the role of class identity. In the book, we see this as the product of material differences among class groups and therefore something that has not changed very much over time. Identities are rooted in current, and to some extent formative, experiences of class division and their persistence reflects those continuing divisions. One could, as Savage does, argue that these identities are actually less strong than competitor identities or, as Kaufmann does,

\footnotetext{
${ }^{1}$ We would like to thank Joe Twyman (YouGov) for giving us tables of turnout from the 52,615 person YouGov 2017 post-election survey and Thomas Leeper (LSE) for help with analysing the YouGov data.
} 
that these identities are in fact very strong but are rooted in a 'clash of worldviews' rather than material conditions. Both of these are very interesting points and if correct both have implications for the future of class identity, albeit very different ones. Nonetheless, it is important to note that in NPC we find nothing to suggest that class identities are themselves in decline. When prompted, very few people struggle to put themselves in a class: less than 10 per cent of people fail to identify as middle or working class in 1964 , even fewer in $2015 .^{2}$ And although we do not address the consequences of class identity in the book, there is evidence that these identities continue to shape behaviours and attitudes. ${ }^{3}$ In the end, however, our argument really depends more on people's objective circumstances. It is these objective differences in people's lives that create identities and ultimately create direct and indirect preferences for particular parties.

Another objection to that first proposition is that class is not the only factor that shapes people's political views. As all four authors note in different ways there are other important, and emerging, divisions within British society. ${ }^{4}$ Eric Kaufmann points to race, Rachel Reeves

\footnotetext{
${ }^{2}$ Mike Savage points to a study from 2009 which suggested that there may have been an over-time decline in the importance of class identity. However, as we note in NPC (p58), this interpretation was reliant on data from 2005, during an economic boom, and more recent evidence from 2015 shows more continuity over time (NPC, p49).

${ }^{3}$ Geoffrey Evans and Jonathan Mellon, 'Identity, awareness and political attitudes: Why are we still working class?', British Social Attitudes vol. 33, 2016, pp. 1-19.

${ }^{4}$ Mike Savage also talks about potential divisions within the class groups that we focus on: a division within the working class manual group and an 'elite' group within the middle class. We find little evidence of major political divides between skilled and unskilled workers which is why we combine them throughout NPC, but the idea of an 'elite' that holds distinctive political preferences certainly deserves further research. Isolating 'the $1 \%$ ' with conventional survey data is very difficult however, and normally requires some kind of innovative research design. See R. Fisman, P. Jakiela, S. Kariv, and D Markovits, 'The distributional preferences of an
} 
and Harold Clarke both discuss age, and Mike Savage mentions gender in addition to race and age. These facets of people's lives are clearly important in shaping their political choices, but in most of the book we are talking about the effects of occupational class and education after holding constant the effects of age, gender, race and indeed other important characteristics like religion, region and trade union membership. Moreover, in general, accounting for these factors actually makes little difference to our conclusions. Apart from anything else, gender and race are not that highly correlated with occupational class or education. This is not to deny that race has a huge impact on vote choice ${ }^{5}$, but it does not lessen the impact of class. Perhaps it is more interesting to think about the interaction between race and class that Eric Kaufmann discusses, or indeed the interaction between age and class that Rachel Reeves mentions. Although we do not explore this in NPC, these are clearly important ideas. Are younger age groups less, or more, divided by education and occupational class than older age groups? As age divisions become more important (of which, more later), and non-white ethnic groups become larger, any future research agenda on class politics in Britain will need to take account of the way in which these different divisions intersect with one another.

These are important points, but actually most of the discussion by the four authors focuses not on our first proposition, but on the second and third. To what extent is our interpretation of the top-down changes and their impact on voters correct? There are three points to make here. The first concerns the logic of Labour embracing the middle classes. If parties want to elite’, Science, vol. 349, no. 6254, 2015, aab0096; B.I. Page, L.M. Bartels, and J. Seawright, 'Democracy and the policy preferences of wealthy Americans’, Perspectives on Politics vol. 11 no.1, 2013, pp. 51-73.

\footnotetext{
${ }^{5}$ While it is true that non-whites vote very differently to whites throughout the post-war period (the former are much more likely to support Labour), race is arguably a much less important cleavage at the aggregate level than class since only a small percentage of the electorate is non-white.
} 
win elections then they need to appeal to large groups within the electorate; whether Labour should continue to pursue, as Clarke puts it, 'its historic mission to further the interests of the workers' is a question for Labour politicians, not us. But ultimately if those politicians cannot combine that shrinking group with others then the party will lose. In that sense, we agree with Mike Savage that 'it is not clear, therefore, that the Labour party had any choice but to try and re-position itself if it wanted to win electoral majorities'.

The second point, and this is perhaps where we slightly disagree with Savage and Clarke, is about perceptions of parties. Clearly policy is an important factor in how parties attract, or repel, different types of voters, but as we argued in chapters 6 and 7 of NPC we should not view a choice between two parties as simply a choice between two bundles of policies. In chapter 7 of NPC we show that it was the combination of party ideological change and change in perceptions of the parties as class parties that altered class voting in the 1990s. People see the parties differently depending on what politicians say, the social background of those politicians and how the media talks about parties. Voters are not just choosing among more or less ideologically distinct parties, but among parties that may or may not directly appeal to certain groups. An element of those appeals which both Eric Kaufmann and Harold Clarke highlight, and which we do not investigate in NPC, is competition at the regional, or constituency, level. Related to this is voter interaction with party members, and the nature of those members, in campaigns. Both are likely to be important in shaping group appeals. But more crucial is simply recognising that perceptions of parties are an important part of any story of vote choice. The huge changes to Labour in the 1990s were not just ideological but affected every aspect of Labour as a political party. This meant that voters actually noticed those changes, updated their perceptions of the party and its ideology and ultimately changed their voting behaviour. 
The third important point relates turnout to these top down party changes. Harold Clarke sets out a spatial model which is central to our story of party convergence. And, as he says, if we consider this model an accurate reflection of reality then that convergence should lead to lower voting rates for everybody: since the parties are the same, 'both working and middle class voters would do equally well whichever party wins'. What we actually document is sharply lower turnout only for the working class and less educated. The way we explain this is to go beyond the spatial model and think of voting as a non-instrumental act. As we argue in chapter 8, if people vote for expressive reasons, to support their 'team', then when parties converge on the middle class we should expect working class political disaffection. In the end, nobody votes to influence the result; they vote to express their belonging to a party or a group. If there are no parties that represent someone's group, then people in that group become less likely to vote, which is exactly what happened in Britain in the 2000s.

This brings us on to the 2017 election, which, in Harold Clarke's words, is 'an interesting test case for Evans and Tilley's supply-side argument'. Arguably, both main parties have changed in different ways since 2015. So what happened to class voting? Using data from the 2015 British Election Study (BES) cross-sectional survey and the 2017 wave of the BES panel survey, Table 1 shows the effect of occupational class and education on Labour vote in 2015 and 2017. Table 2 does the same for the Conservative vote. These figures are predicted probabilities from models that simultaneously include education and occupational class, as well as other potential confounding factors like region, gender and age. We use the same occupational class categories as in NPC: old middle class refers to people in managerial jobs and small employers; new middle class refers to people in professional jobs; junior middle class refers to people in routine clerical jobs; and working class refers to people in manual 
jobs. Also as in NPC, retired and unemployed people are classified on the basis of their last job and people with no job are classified using their spouse's occupation. Unlike in NPC we just look at voters here as the British Election Panel Study systematically underrepresents non-voters. Nonetheless the basic pattern that we talk about in chapter 7 of NPC is clear. In particular, voters with new middle class jobs were just as likely to vote Labour in 2015 as voters with working class jobs. There are also some education effects. People with low and high levels of education are more likely to vote Labour than those with middling levels of education. Interestingly, and remembering that we are holding constant people's gender, age and region, the impact of education and occupation did not really change much between 2015 and 2017. The effect of having a degree became slightly more important, but the patterns of Labour vote by occupational class and education are almost constant.

\section{TABLES 1 AND 2 ABOUT HERE}

Table 2 shows that the Conservative vote changed a little more. There are two obvious changes. First, people in working class jobs became more likely to support the Conservatives. Second, those with higher education became less likely to support the Conservatives. This hints at the party changes that really mattered in 2017, which were the demise of UKIP as a major party and the repositioning on the back of Brexit of the Conservatives as a less socially liberal party. Since the majority of the social conservatives that voted for UKIP switched to the Conservatives, and since social conservatives are more likely to be working class and less likely to have a degree, the Conservative vote became a bit more working class in 2017 . Heath and Goodwin show a similar story at the constituency level. ${ }^{6}$

\footnotetext{
${ }^{6}$ O. Heath and M.J. Goodwin, 'The 2017 general election, Brexit and the return to two-party politics: An aggregate-level analysis of the results', Political Quarterly, vol. 88, no. 3, 2017, pp. 345-358.
} 
Why did, as Clarke puts it, the 'old-line socialist policy appeals articulated by Labour leader Jeremy Corbyn' not translate into traditional class voting for Labour? There are two possible reasons. First, and as we emphasised in the book, it is not just how parties change that is important, but also how voters notice those changes. By far the most memorable policy pledges of the campaign were Labour scrapping tuition fees and the Conservatives' social care reforms. ${ }^{7}$ In terms of income redistribution, the former is somewhat regressive and the latter mildly progressive. It may be that that the two parties were not seen by the average voter as representing very distinct positions on the economic left-right dimension, or at least no more so than in 2015.

Second, even if voters did think that Labour had moved to the economic left, it seems likely that voters had even more of a sense of difference between the two parties in terms of social liberalism. This is partly related to Brexit policy, but runs far wider than this, think of ‘questions about national security’ mentioned by Rachel Reeves or immigration. As we predicted in NPC (p194): 'Labour under Corbyn is not just more left-wing but also more socially liberal, especially on key issues like immigration. This suggests that Labour will find it difficult to regain its old "core" voters who tend to be more socially conservative than the average person.' Certainly this fits with increased support among working class voters for the Conservatives in 2017. It also fits with the probable changes to perceptions of the parties as 'class parties'. These are unlikely to have greatly altered between 2015 and 2017, but, as well

7 A. Wells, 'Manifesto destinies', YouGov Report, $25^{\text {th }} \quad$ May 2017. https://yougov.co.uk/news/2017/05/25/manifesto-destinies/ (accessed $1^{\text {st }}$ September 2017). 
as the Labour party trying to appeal to the young, one of the main changes was the Conservative party actively trying to court working class voters.

Putting this year's election into the context of the seventy years of British politics that we cover in the book, class voting in 2017 appears fairly unexceptional compared to the recent past. Labour voting patterns by class and education look remarkably similar to 2015, which are, in turn, not hugely different to any election after 1997. The Conservative vote changed more as a result of the parties moving apart on social liberal-conservative issues and the collapse of the party that was previously a home for many social conservatives. Nonetheless there is also a great deal of continuity over the last 20 years.

The real test of our argument that the 2017 election allows relates to turnout. At the end of NPC we suggested that class non-voting would be unlikely to disappear. Partially this was because of what we expected parties to do, but it was also because voting is a habit which when lost is difficult to regain. It is always dangerous to make predictions, but that piece of soothsaying looks remarkably accurate. Table 3 shows turnout by combined occupational class and educational groups in 2010, 2015 and 2017. The data from 2017 come from the YouGov post-election survey of over 50,000 people ${ }^{8}$ and the data from 2010 and 2015 come from the relevant British Election Studies. Crucially these are predicted probabilities of turnout (validated turnout in 2010 and 2015) from models that hold age constant. This is similar, although not identical, to figure 8.3 in NPC that tracks turnout rates over time for what we call the intelligentsia (people with degrees and new middle class jobs) and the

\footnotetext{
${ }^{8}$ The total sample is 52,615 people drawn from the YouGov panel. Fieldwork was carried out between $9^{\text {th }}$ and $13^{\text {th }}$ June 2017. After weighting, overall turnout in the sample is 69 per cent, the same as the official turnout figure.
} 
proletariat (people with no qualifications and working class jobs). ${ }^{9}$ In that chapter we argue that class non-voting is a new and important facet of how class affects politics. And there is little reason to change this claim. In 2015, the difference in turnout between the two groups was 23 per cent and at the election this year it was over 30 per cent. A similar calculation for the 1987 election gives a difference of just 3 per cent. While one might quibble about data comparability, there is absolutely no evidence of this gap shrinking; indeed if anything it appears to have widened over the last two years.

The reasons we gave for the growth of class non-voting over the 2000s were largely due to changes to the Labour party that made traditional supporters less likely to participate. At the end of chapters 8 and 9 we speculated about the likelihood of this changing. We thought that class non-voting was here to stay, arguing that many working class voters for the SNP and UKIP were likely to exit politics over the medium term. We suggested that 'working class voters are likely to stay with the SNP or stop voting' (NPC, p187) and that while continuing class divisions in UKIP were likely, the question was whether UKIP would be able to 'maintain its existence after the EU referendum' (NPC, p187). Both the SNP and UKIP disproportionately lost voters to non-voting in 2017, and this is partially why the class turnout

\footnotetext{
${ }^{9}$ The numbers are not identical to those in figure 8.3 in NPC as the models and measures have been simplified to produce comparability with the YouGov data. The models only include age, education and occupational class here, whereas in NPC there is a longer list of other controls. This is less important than the fact that the measures of education and occupational class have reduced numbers of categories. For the BES data, we combine the foremen and supervisor occupational class group with the working class occupational group. This is then roughly equivalent to people in the $\mathrm{C} 2+\mathrm{D}$ market research categories that YouGov use. We also combine the new middle class and old middle class occupational class groups to give a professional/managerial category which is broadly equivalent to the A and B market research categories. Low education here is taken to mean GCSE level or below, whereas in NPC low education normally means qualifications below GCSE/ O-level.
} 
gap increased. But the turnout gap also increased because middle class non-voters, especially younger graduates, became slightly more likely to vote. Labour mobilised new voters to some extent in 2017, but the party platform of social liberalism and economic leftism mobilised middle class social liberals, not working class economic leftists.

Part of this also goes back to the idea of habitual non-voting. It is difficult to remobilise people who become disillusioned with the choice of parties and then choose not to vote in multiple elections. One might think that new voters have no habit, so it is the party choice today that matters for them, not the party choice of 20 years ago. Nonetheless the pattern of class non-voting in Table 2 is actually rather similar across age groups, and is possibly even more stark amongst the young. The YouGov data show that 81 per cent of 18-29 year olds with a degree and a professional/managerial job voted in 2017. This compares to 63 per cent of 18-29 year olds with a medium level of education in clerical middle class jobs and only 32 per cent of 18-29 year olds in manual jobs with a low level of education. There is little here to suggest there that differential turnout will disappear as the electorate ages.

The 2017 election was interesting for lots of reasons, but those reasons do not include radical changes to class non-voting. Class voting changed a little more as working class people became a bit more Conservative. Why? Because the division between the two main parties centred more on policies with which the average working class voter has more in common with the Conservative party. This is a good illustration of top down change: the parties changed tack and voters responded. The emergence of alternative divisions based on age also supports this top down argument. Age differences become more pronounced in 2017 precisely because party differences, whether policy or rhetoric, were more apparent on the 
social liberal-conservative dimension of politics. Older people have very different views to younger people on these issues, so differences in vote choice by age became more important.

In the end, what parties do, what they say and what they look like affects how groups line up behind those parties. Class voting was pre-eminent when parties were organised around the economic policy divisions generated by class for the fifty years after the war. Party differences today are increasingly aligned around issues that also divide the electorate by class, but divide people by age to a much greater extent. In that sense, maybe age is the new class and in 50 years' time it may be The New Politics of Age that is being reviewed in this journal. 
Table 1: $\quad$ Impact of occupational class and education on Labour vote in 2015 and 2017

\begin{tabular}{|c|c|c|}
\hline & \multicolumn{2}{|c|}{ \% Labour vote } \\
\hline & 2015 & 2017 \\
\hline Old middle class & $28 \%$ & $31 \%$ \\
\hline New middle class & $40 \%$ & $41 \%$ \\
\hline Junior middle class & $34 \%$ & $41 \%$ \\
\hline \multirow[t]{3}{*}{ Working class } & $39 \%$ & $44 \%$ \\
\hline & \multicolumn{2}{|c|}{$\%$ Labour vote } \\
\hline & 2015 & 2017 \\
\hline Degree & $40 \%$ & $48 \%$ \\
\hline A-level & $34 \%$ & $43 \%$ \\
\hline O-level & $35 \%$ & $41 \%$ \\
\hline None & $44 \%$ & $46 \%$ \\
\hline
\end{tabular}

Note: The numbers here show predicted probabilities from multinomial logistic regression models that predict vote choice (for voters) in the 2015 and 2017 general elections. As well as occupational class and education, these models include controls for gender, age and region. For 2017, occupational class is measured at wave 9 of the panel. The predicted occupational class probabilities are for a man in his 40s who lives in the East Midlands and has middling educational attainment. The predicted education probabilities are for the same type of person who is in the junior middle class category.

Source: British Election Study 2015; British Election Panel Study 2017. 
Table 2: $\quad$ Impact of occupational class and education on Conservative vote in 2015 and 2017

\begin{tabular}{lccc}
\hline & 2015 & \% Conservative vote & \\
& & 2017 \\
Old middle class & $54 \%$ & $59 \%$ \\
New middle class & $37 \%$ & $49 \%$ \\
Junior middle class & $46 \%$ & $50 \%$ \\
Working class & $27 \%$ & & \\
& & \% Conservative vote & \\
& & & 2017 \\
& 2015 & & $39 \%$ \\
Degree & $46 \%$ & $48 \%$ \\
A-level & $49 \%$ & $50 \%$ \\
O-level & $47 \%$ & $44 \%$ \\
None & $43 \%$ & \\
\hline
\end{tabular}

Note: The numbers here show predicted probabilities from multinomial logistic regression models that predict vote choice (for voters) in the 2015 and 2017 general elections. As well as occupational class and education, these models include controls for gender, age and region. For 2017, occupational class is measured at wave 9 of the panel. The predicted occupational class probabilities are for a man in his 40s who lives in the East Midlands and has middling educational attainment. The predicted education probabilities are for the same type of person who is in the junior middle class category.

Source: British Election Study 2015; British Election Panel Study 2017. 
Table 3: $\quad$ Turnout by education and occupational class in 2010, 2015 and 2017

Turnout 2010

Turnout 2015

Turnout 2017

Professional/managerial and high education Working class and low education

$81 \%$

$59 \%$

$22 \%$

Difference

Note: The numbers here come from logistic regression models that predict turnout in the 2010, 2015 and 2017 general elections. The models include age-group (six categories), education (high, middle and low) and occupational class (professional/managerial, routine clerical and manual). Occupational class is measured using the NPC classification for the BES data in 2010 and 2015, and market research categories A-E for the YouGov data in 2017. People in the old middle class and new middle class groups in 2010/2015 are treated as equivalent to those in A and B market research categories in 2017 and form the professional/managerial group. People in the foremen and working class groups in 2010/2015 are treated as equivalent to those in the C2 and D market research categories in 2017 and form the working class group. People with high education are those with a degree and people with low education are those with qualifications at GCSE level or below. The figures here predict turnout for someone aged in their 40 s.

Source: British Election Study 2010 and 2015; YouGov post-election survey 2017. 